\title{
Legal and health aspects of sanitary waste management in Italy
}

\author{
M. Di Basilio \& M. Papacchini \\ ISPESL - National Institute for Occupational Safety and Prevention, \\ DIPIA - Department for Production Plants and Interaction with the \\ Environment, Italy
}

\begin{abstract}
Sanitary wastes represent an important health aspect of extreme complexity on account of their heterogeneity, their quantitative and typological growing trend and of their simultaneous belonging to different hazardous classifications. The purpose of this study is to review the occupational exposure and risks for workers involved in the sanitary waste collection and management industry. Sanitary Wastes (S.W.) can be categorized as infectious or non-infectious. Workers of the sector considered are exposed to the most common etiological agents such as the Hepatitis A, Hepatitis B, Hepatitis C and HIV viruses, bacterial infections caused by the Bacillus, Staphylococcus and Mycobacterium varieties and fungal infections from the Aspergillus variety, mainly due to accidental events or faulty application of safety procedures. The nature of the relevant biological agent depends on the processing unit in question. Referring also to current Italian legislation and to risks connected to S.W. management, this study will consider tools to put in practice a rigorous hygienic management of S.W., in order to minimize all risks connected with their production, collection and disposal. An important sector of this study will be dedicated to S.W. classification, differentiating infectious from non-infectious waste, in order to choose the most acceptable treatment method for the various types of waste, reducing risks for workers due to the presence of non-infectious hazardous substances. All actions taken in order to protect persons handling S.W. will be analysed for each phase of their packaging, handling, transportation and storage. Keywords: sanitary wastes, management, professional exposure, Italian legislation.
\end{abstract}




\section{Introduction}

Various aspects contribute to the great interest aroused by sanitary wastes. One of these concerns health and hygiene. Other aspects regard the management and heterogeneous characteristics of waste, the growth trend in type and quantity of wastes and the fact that they can belong contemporaneously to more than one risk category. According to the World Health Organisation, potentially infectious sanitary wastes represent a risk for the environment, the health of patients, health facility staff and public health in general (on account of risks connected with transportation and final disposal).

\section{Aim}

The aim of this study is to analyse occupational exposure and risks in spinnaret workers during sanitary waste collection and management. These wastes can be classified basically as infectious and non-infectious. Infectious wastes usually include those of human, animal or of biological origin generally, and all elements that may have been contaminated by pathogens. Non-infectious wastes include toxic chemical substances (solvents, oils, disinfectants, etc.) and cytotoxic substances (medicines). Numerous data on exposure are available for the latter sector.

Workers in the sector examined in this study are exposed to etiological agents such as: hepatitis A, hepatitis B, hepatitis $\mathrm{C}$ and HIV virus, bacterial infections caused by the Bacillus, Staphylococcus and Mycobacterium varieties, and fungal infections from the Aspergillus variety. In most cases occupational exposure to these agents occurs accidentally or is due to incorrect application of safety procedures.

By examining existing Italian legislation in this sector and the risks involved in sanitary waste management, this study analyses regulations currently in place for stringent hygienic management of sanitary wastes with a view to reducing the risks involved in each of the required phases.

An important part of the study is devoted to the classification of sanitary wastes where a clear distinction is made between infectious and non-infectious wastes, since this subdivision is important in identifying adequate methods of treating different types of waste and of reducing risk.

\section{The size of the problem}

In recent years, the problem of wastes, especially sanitary wastes (SW), has taken on considerable importance due to a continual increase in the use of throwaway materials, to the growing presence of dangerous or potentially hazardous substances and to their infectious nature. Even though infectious SW represent only a small proportion of the overall volume of wastes produced, they are nevertheless a problem on account of their special characteristics and the lack of facilities for adequately treating this type of waste. 
By way of example, a hospital produces from 1.5 to $15 \mathrm{~kg}$ of waste per patient per day, whose composition (usually made up of $75 \%$ "urban-type waste" and $25 \%$ special hospital or potentially infectious waste) depends not only on the activities performed in the different hospital departments, but also on the type of hospital involved (Angelini et al [1]).

\section{Occupational exposure and associated risks}

Many studies have demonstrated that sanitary waste disposal workers can come into contact with biological agents more frequently than other occupational categories (Canegallo et al [2]). As regards occupational exposure (biological, infectious, chemical risk), the productive sectors mainly involved in the management of sanitary wastes are: hospitals, diagnosis and research laboratories, stables, activities connected with disinterment and exhumation. The commonest carriers are biological materials such as blood, urine, cerebrospinal and seminal fluids, faeces, sputa, organs and/or tissue fragments, animal carcasses and chemicals such as disinfectants (aldehydes, alcohols, phenols, etc.), detergents, medicines (chemotherapies, antibiotics, hormones). Moreover, we must remember that even small quantities of pharmacological substances usually have a high active capacity and this increases the risk for those handling them. In this case eventual pathologies are caused by genotoxicity (chromosome aberrations, mutagenic effects on DNA), carcinogenesis, teratogenesis and a reduction in fertility. Stables deserve a special mention since, like laboratories, they are defined according to the risk category of the biological agents studied there. There are four levels of biosafety that take into consideration different classification factors. These include the pathogenicity of microorganisms, methods of transmission and possible hosts, the availability of effective preventive measures and treatment. For example, in the veterinary field, waste disposal workers can come into contact with and be infected by endo- and ectoparasites that are the natural hosts of stabled animals (infections from caseworm and cryptosporydius); moreover, some animal zoonoses can be transmitted to humans (brucellosis, leptospirosis, hemarrhagic fever, etc.). Immune-type reactions can be caused by the dissemination of hairs or other components of animal origin that act as allergens. In the hospital sector, the commonest etiologic agents workers are exposed to are: hepatitis A, hepatitis B, hepatitis C, HIV viruses, bacteriological infections due to many different germs such as Bacillus, Staphylococcus, Mycobacterium, fungal infections from the Aspergillus variety, parasitosis; most of these occur accidentally or through the faulty application of safety procedures (Trevisan et al [3], Franchi et al [4], Lopez Hernandez et al [5]). The type of biological agent involved depends on the process units in which exposed workers are employed, but in the case of exposure to non-infectious agents, studies usually reveal exposure to bioaerosols containing live bacteria, moulds, bacterial mycotoxins and endotoxins. In this case reactions are prevalently immunologic (bronchial asthma, dermatitis, allergic rhinitis, alveolitis) or toxic (absorption of endotoxins and $\beta$ 1-3 glucans) (Barth et al [6]). 


\section{Legal framework}

\subsection{National legislation on hospital/sanitary wastes up to 1997 ("Ronchi" Decree)}

Up to 1997, national legislation concerning hospital/sanitary wastes was often influenced by urgent or contingent circumstances. Consequently it was not always introduced in an organic way into what was already a disjointed and complex national legal framework on waste materials.

The Legislative Decree 5 February 1997, n. 22 [7] made a significant attempt to redress this situation.

With regard to sanitary wastes, after reviewing all the regulations, the Ronchi Decree

- confirms the fact that wastes derived from sanitary activities are to be considered special wastes;

- classifies sanitary wastes as dangerous in compliance with the European list of dangerous wastes;

- lays down rules concerning the temporary storage of sanitary wastes, the responsibility of hospital managers and the final destination of sanitary waste;

- $\quad$ introduces a register for the loading and unloading of wastes;

- defers the definition of further sanitary waste management methods and the identification of sanitary wastes requiring special disposal systems to later legislation

On the basis of the definition of sanitary waste in code 18 of the European list of dangerous wastes, this Decree refers first of all to an approach that requires only potentially infectious wastes that represent a real hazard for public health to be subject to special laws.

The law requires sanitary wastes to be incinerated; disposal in a rubbish tip is allowed only in the case of urgent and contingent circumstances, and constitutes an exception.

In point of fact, a distinction has been made between dangerous wastes that must be incinerated and all other wastes (kitchen, office waste, etc.) that must be disposed of according to the category to which they belong. In short, this special law has been applied only to the field of sanitary wastes (Apat [8]).

As for the intermediate phases of sanitary waste management, the Decree lays down rules for temporary storage and sterilisation, deferring regulation of further phases to subsequent administrative action.

In the case of temporary storage, the law provides for a maximum of 5 days for quantities exceeding 200 litres, and 30 days in all other cases, provided temporary storage takes place on the production site and under conditions that cannot cause alterations that could involve health risks.

In the case of sterilisation of dangerous sanitary wastes off the site of the hospital that produced them, the Decree states that this is subject to authorised procedures similar to those required for other types of waste. 


\subsection{Ministry Decree 26 June 2000, n. 219}

This regulation [9] sets out all the specific technical ${ }^{\text {rules }}$ required under art. 45 of the Ronchi Decree, i.e.:

- collection, disinfection, sterilisation, transportation, recovery and disposal of dangerous sanitary wastes;

- identification of cemetery wastes and the technical rules for its management;

- identification of elements of sanitary wastes included as urban waste matter;

- identification of elements of sanitary wastes that require special disposal systems

This regulation includes important references to true sanitary wastes, i.e. dangerous and potentially infectious wastes. It also regulates the following types: wastes requiring special management methods (unusable medicines or those that are past their use-by date, including antineoplastic medicines, laboratory animals and drugs), exhumation and disinterment wastes, non-hazardous sanitary wastes, included in the definition of urban waste, and dangerous non-infectious sanitary wastes (Angelini et al [1]).

On the subject of the handling of potentially infectious sanitary wastes, the MD carefully states that from the very first stages of waste production, appropriate and easily identifiable strong disposable packaging must be used for collection, storage and removal so as to prevent persons or things coming into contact with these wastes before final disposal.

The decree no longer requires wastes to be disinfected before removal. As regards the creation and management of sterilisation processes for potentially infectious wastes, the MD states: " The sterilisation of dangerous sanitary wastes performed off the production site is subject to authorised procedures".

On the other hand, the MD explicitly states that sterilisation plants located on hospital premises need not be authorised (articles 27 and 28 Legislative Decree 5 February 1997, n. 22) provided these plants treat only the sanitary wastes produced in that particular hospital.

In any case, this concessionary regime for the auto-disposal of wastes falls outside the jurisdiction of "dangerous" waste disposal (art. 32, comma 6 and art. 3, comma 2 of Directive 91/682/EC). The MD also aims at reducing waste by separating it at source and thereby diminishing the quantity of waste sent for disposal, and also at reducing the hazardous nature of wastes by separating out the most contaminating parts.

\subsection{Italian Presidential Decree 15 July 2003, n. 254}

This Decree [10], which lays down new regulations concerning the management of sanitary and special wastes that are equally as dangerous as potentially infectious ones, abrogates all former regulations, even rules of law, on the subject of sanitary wastes (including art. 45, Legislative Decree 22/97) and 
unconditionally addresses all waste producers. This legislation is still in force even following the publication of the new Consolidation Act on the environment; an Act that includes a section on wastes, but that does not change the validity of the regulations of the Decree in question.

The Decree defines as sanitary wastes all those listed in its enclosures I and II, and divides up relative case records more than in the past. They thus include those produced by private and public organisations (referred to in Leg. Decree 509/92) engaged in medical and veterinary prevention, diagnosis, treatment, rehabilitation and research, and also special wastes produced outside health facilities (with the exception of sanitary napkins), that are nevertheless classed as potentially infectious dangerous wastes.

These wide-ranging new regulations apply to all health facilities (hospitals, etc.) and all public and private health workers (general practitioners even when operating outside their own surgeries, dental surgeons, professionals, etc.) as they all they produce special wastes. Thus microbiological water and food testing laboratories, and also beauty parlours and the like form part of the latter categories since throwaway sharps come into contact with vascularised skin. This means that even small facilities must now follow all the requirements necessary for the management of this type of waste: temporary storage methods, a loading and downloading register, annual MUD declaration.

The Presidential Decree therefore sets out rules for waste management that are again based on the type of wastes involved, but it includes a few exceptions compared to previous legislation.

Non-hazardous sanitary wastes can be temporarily stored on the production site for up to a year provided they do not exceed $200 \mathrm{mc}$. However, larger quantities of waste must be disposed of every three months.

Potentially infectious sanitary wastes can be temporarily stored for up to thirty days if they do not exceed 200 litres, or for up to a maximum of five days after the container is closed; they must also be in compliance with hygiene and safety requirements and under the responsibility of the producer. These wastes must be kept in special packaging suitable for sharps or non-sharp material. Disposal must be by incineration in authorised plants and, if wastes pose a further hazard (dental amalgam with biological fluids, etc.), they should be disposed of in plants reserved for dangerous wastes. The Presidential Decree also states in this type of disposal, there must be no direct handling of waste during furnace loading.

Wastes can also be sterilised so as to simplify the disposal process, but this involves very complex and burdensome procedures that are rarely available in small health facilities. In any event, the temporary storage, collection and transportation of this type of waste are regulated by technical provisions for the management of special non-hazardous wastes.

As to other wastes, under this provision, stone and inert materials used in cemetery constructions are exempted from the need for authorisation, whereas management rules regarding sanitary wastes assimiliable to urban wastes, remain basically unaltered. 


\section{Conclusions}

Given that infection may occur after a single exposure, it is vital to minimize risks by using a control plan to prevent exposure. In fact current engineering know-how, up-to-date safety apparatus (double containers, puncture resistant polyethylene containers for sharps), the implementation of good laboratory practices (use of gloves, protective clothing) and staff training now enable us to minimize risks. Our review of recent legislation in this field shows that regulations have now been directed at containing risks associated with the management of sanitary wastes. This has been done by tackling important questions of management such as the identification of waste categories in which there is an unequivocal risk of infection, the packaging of wastes for storage and transportation, the sterilisation of sanitary wastes in compliance with validated technical regulations; and by attempting, when this is feasible and safe, to encourage recycling.

\section{References}

[1] Angelini, p., Meneghini, F., Gataleta F., La gestione dei rifiuti sanitari, Centro Editoriale e Librario: Università degli Studi della Calabria, 2000.

[2] Canegallo, C., Ciliberti, R., Melioli, R., Il rischio da agenti biologici nel laboratorio di ricerca e di analisi cliniche. Ambiente e Sicurezza sul Lavoro, 11, pp 57-62, 1997.

[3] Trevisan, A., Stocco, E., Fanelli, G., Bicciato, F., Paruzzolo, P., Seroprevalence of hepatitis A markers in subject exposed to biologic risk. Internal Archives of Occupational and Environmental Health 72(2), pp 125-127.

[4] Franchi, A., Amicosante, M., Rovatti, E., Bonini, R., Marcheggiano, P., Girardi, E. et al., Evaluation of a western blot test as a potential screenig tool for occupational exposure to Mycobacterium tubercolosis in health care workers. The Journal of Occupational and Environmental Medicine 42(1), pp 64-68, 2000.

[5] Lopez Hernandez, B., Almagro Nievas, D., Cabrera Castillo, MJ., Seroprevalence of brucelosis in the workers of a plant of treatment of sanitary wastes. Med Clin, 120(10), pp 376-7, 2003.

[6] Barth, E., Talbott, N., Gable, R., Richter, S., Reponen, T., Evaluation of bioaerosol exposures during conditioning of biofilter organic media beds. Appl. Occup. Environ. Hyg. 17(1), pp 10-4, 2002.

[7] Decreto Legislativo 5 febbraio 1997, n. 22, Attuazione delle direttive 91/156/CEE sui rifiuti, 91/689/CEE sui rifiuti pericolosi e 94/62/CE sugli imballaggi e sui rifiuti di imballaggio, G.U. n. 38, 15 febbraio 1997 Supplemento Ordinario n. 33.

[8] APAT, Il sistema di contabilità dei rifiuti sanitari: una indagine conoscitiva, Rapporti, 33, Roma, 2003. 
134 Management of Natural Resources, Sustainable Development and Ecological Hazards

[9] Decreto 26 giugno 2000, n. 219, Regolamento recante la disciplina per la gestione dei rifiuti sanitari, ai sensi dell'art. 45 del decreto legislativo 5 febbraio 1997, n. 22, G.U. n. 181, 4 agosto 2000.

[10] Decreto Presidente della Repubblica 15 luglio 2003, n. 254, Regolamento recante disciplina della gestione dei rifiuti sanitari a norma dell'art. 24 della legge 31 luglio 2002, n. 179, G.U. n. 211, 11 settembre 2003, 